\title{
ПРОБЛЕМЫ ПРАВОВОГО РЕГУЛИРОВАНИЯ АРЕНДЫ ГОСУДАРСТВЕННОГО И МУНИЦИПАЛЬНОГО ИМУЩЕСТВА
}

\section{LEGAL REGULATION IMPROVEMENT OF STATE AND MUNICIPAL PROPERTY RENTING}

\section{Shaydullina}

Summary: This article substantiates the relevance of issues related to the lease of state and municipal property. The concept of property lease, the specifics of the legal regulation of this area, the specifics of concluding lease agreements for municipal and state property are analyzed. The subjects of municipal, state and other property are disclosed. A legal gap has been identified related to participation in lease legal relations of enterprises, in whose authorized capital the share of municipal and state institutions is more than $50 \%$. A method for its elimination at the level of the legislation of the subjects of the Federation and federal legislation is proposed.

Keywords: agreement, regulation, lease, lease agreement, property, law, state and municipal property.

\author{
Шайдуллина Венера Камилевна \\ К.ю.н., доцент, Финансовый университет при \\ Правительстве Российской Федерации (г. Москва) \\ VKShajdullina@fa.ru
}

Аннотация: В настоящей статье обоснована актуальность вопросов, связанных с арендой государственного и муниципального имущества. Проанализировано понятие аренды имущества, специфика нормативно-правового регулирования данной сферы, особенности заключения договоров аренды муниципального и государственного имущества. Раскрыты субъекты муниципальной, государственной и иной собственности. Выявлен правовой пробел, связанный с участием в арендных правоотношениях предприятий, В чьем уставном капитале доля муниципальных и государственных учреждений более 50\%. Предлагается способ его устранения на уровне законодательства субъектов Федерации и федерального законодательства.

Ключевые слова: договор, регулирование, аренда, договор аренды, имущество, закон, государственное и муниципальное имущество.

ную плату. Пользоваться и владеть имуществом, полученным на основе договора аренды, арендатор должен в согласии с условиями, прописанными в соглашении. Если договор аренды не содержит четких условий, то пользование и владение арендованным имуществом должно осуществляться с учетом прямого назначения имущества. Понятием «собственность на имущество» охватываются такие права:

- право распоряжения (арендодатель может обменивать, дарить, продавать и иным образом распоряжаться арендованным имуществом);

- право пользования (арендодатель может пользоваться арендованным имуществом и извлекать доход от такого использования);

- право владения (арендодатель вправе физически обладать арендованным имуществом).

Широкое и повсеместное развитие российского рынка коммерческой недвижимости привело к увеличению числа предприятий и индивидуальных предпринимателей, чьей главной сферой деятельности выступает получение прибыли от сдачи имущества (движимого или недвижимого) в аренду. Этот вид коммерческой деятельности выгоден обеим сторонам - и арендатору, и арендодателю. Выгода арендодателя выражена в виде платы от пользования арендуемым имуществом. Арендатор, в свою очередь, может варьировать требуемый объем и перечень имущества, необходимого и достаточного для 
обеспечения деятельности предприятия. В некоторых случаях аренда позволяет экономическим субъектам снизить свои риски и выглядеть в глазах кредиторов более надежными [2].

Положения, регулирующие арендные отношения, изложены в гл. 34 ГК РФ. Эти положения обладают универсальным (общим) характером и распространяют свое действие на все существующие виды аренды (в т. ч. субаренду).

Действующее гражданское законодательство содержит положения, регулирующие отношения, вытекающие из договора аренды. В частности, в ГК РФ установлено следующее:

- понятие аренды (ст. 606);

- объекты аренды; обязанность указать в договоре аренды данные, позволяющие с определенной точностью установить имущество (движимое или недвижимое), которое подлежит передаче по договору (ст. 607);

- перечень условий и требований для заключения и государственной регистрации договора аренды (ст. 609);

- условие о сроке аренды (ст. 610);

- порядок передачи имущества арендатору; ответственность арендодателя за недостатки и порчу имущества; сроки и порядок изменения размера арендной платы (ст. 611, 612, 614);

- условие о субаренде, порядок использования имущества (ст. 615);

- сроки проведения ремонта, обязательства арендатора и арендодателя по содержанию имущества (ст. 616);

- порядок прекращения договора субаренды в случае досрочного прекращения основного договора; условия сохранения договора в действии в случае замены арендатора или арендодателя (ст. 617, 618);

- случаи досрочного прекращения договорных отношений по инициативе арендатора или арендодателя (ст. 619, 620);

- порядок возврата имущества, переданного в аренду; порядок взаиморасчета между сторонами при проведении улучшений арендуемого имущества - неотделимых или отделимых (ст. 622, 623);

- условия выкупа имущества, переданного по договору аренды (ст. 624).

В соответствии с действующим гражданским законодательством, если арендатор добросовестно исполняет свои обязанности, своевременно вносит арендную плату, использует имущество по назначению, то он имеет приоритетное право на продление договора на новый срок. Это правило закреплено в ст. 621 ГК. Если в планах арендатора продолжать договорные отноше- ния, то он должен письменно сообщить об этом своему арендодателю. Уведомление должно быть направлено в срок, обозначенный в договоре аренды. При отсутствии такого срока уведомление должно быть представлено в разумный срок до момента окончания действующего договора.

Закон не предусматривает никаких ограничений в части сторон договора аренды. Арендодателем может выступать любой собственник имущества или лицо, которое наделено правом хозяйственного ведения. В последнем случае необходимо согласие собственника. Арендатором может выступать любое дееспособное лицо. В некоторых случаях к арендаторам могут предъявляться дополнительные требования (к примеру, наличие лицензии). Заключать договор аренды могут любые субъекты: физические лица, организации, некоммерческие и коммерческие предприятия, государство, муниципальные, административно-территориальные и национально-государственные образования.

Виды аренды: прокат транспорта; аренда участков земли и предприятий; аренда строений; аренда интеллектуальной собственности; лизинг; прокат движимых объектов. Отдельным видом является субаренда.

В России признается и защищается три формы собственности (п. 1 ст. 212 ГК РФ):

- государственная;

- муниципальная;

- частная.

Выступать в суде, приобретать и осуществлять имущественные обязанности и права от имени РФ и субъектов Федерации могут органы государственной власти в рамках компетенции, которая установлена соответствующими актами (п. 1 ст. 125 ГК).

Понятием «муниципальная собственность» охватывается имущество, принадлежащее муниципальному образованию. Возникновение этой формы собственности связано с приватизацией государственной собственности. Муниципальная собственность отличается от государственной по объектам, субъектам, содержанию, основаниям приобретения права собственности и основаниям его прекращения, а также по целям использования (п. 1 ст. 215 ГК РФ). Выступать в суде, приобретать и осуществлять имущественные обязанности и права от имени муниципальных образований могут органы местного самоуправления в рамках своей компетенции, установленной соответствующими актами [3].

Положения, регламентирующие право муниципальной и государственной собственности в России, закреплены в ГК РФ, Постановлении Верховного Суда РФ № 3020-1 от 27.12.1991 г., Распоряжении Президента РФ № 
114-рп от 18.03.1992 г., иных нормативно-правовых акTax.

Каждый участник арендных отношений преследует рыночные цели. Естественное желание арендодателя увеличение прибыли от аренды движимого или недвижимого имущества [4]. Желание арендатора - минимизация затрат, связанных с арендой имущества. И, если для коммерческих предприятий извлечение максимальной прибыли очевидно, то для муниципальных и государственных организаций этот тезис еще и законодательно закреплен [6].

При аренде муниципального и государственного имущества порядок вступления в договорные отношения регулируется положениями ст. 17.1 Закона РФ № 135-Ф3 от 26.07.2006 года «О защите конкуренции». Эта статья введена Законом № 108-Ф3 от 30.06.2008 г. Суть требований, установленных этой статьей, заключается в следующем:

а) в обеспечении конкурентного и справедливого доступа организаций к такому ограниченному ресурсу, как муниципальное и государственное имущество, вовлеченное в хозяйственный оборот [5];

б) в обеспечении публичных интересов и их соблюдении.

С экономической позиции проведение торгов позволяет государству с большей эффективностью распоряжаться своим имуществом, передавая права пользования или владения данным имуществом лицу, предложившему самую высокую цену за право заключить договор [7]. В ст. 17.1 Закона № 135-Ф3 закреплен перечень предприятий-исключений, с которыми не проводятся аукционы и конкурсы перед заключением договора аренды. К их числу относятся все муниципальные и государственные учреждения. Это исключение в полной мере отвечает положениям Закона № 44-Ф3 от 05.04.2013 года [8].

То же самое касается закупочных процедур, в которых участвуют некоторые немуниципальные и негосударственные предприятия, упомянутые в п. 2 ст. 1 Закона № 223-Ф3 от 20.07.2011 г. [9] Каждый участник государственных (муниципальных) закупок должен соблюдать требования, закрепленные в Положении о закупках. Согласно п. 2.1 ст. 2 Закона № 223-Ф3, данные предприятия должны использовать типовое положение о закупках. Здесь возникает явное противоречие. Его суть в том, что арендодатель строит закупку так, чтобы добиться заключения договора аренды по более высокой стоимости, а арендатор преследует противоположную цель.

В ходе реализации Постановления Правительства города Москвы № 67-ПП от 24.02.2012 г. разработано Постановление № 441-ПП от 05.07.2013 года [10]. Им уста- навливается перечень общих требований и условий, заложенных в основу при разработке Типовых положений о закупках учреждений, подведомственных Правительству г. Москвы. В перечне нет требований о закупке услуг у единственного поставщика, а также о возможности закупки услуг аренды на аукционе или конкурсе с повышением цены договора. Указанные позиции отсутствуют и в тексте Типового положения о закупке товаров, работ услуг (далее - Типовое положение) . Таким образом, можно говорить о наличии явного правового пробела, который необходимо устранить.

В настоящее время существуют определенные недостатки в нормативно-правовом регулировании арендных отношений и процедуры заключения договора аренды имущества, находящегося в собственности муниципального образования или государства, если арендатором выступает предприятие, в чьем уставном капитале доля государственного участия более 50\%, либо предприятие, из числа поименованных в п. 2 ст. 1 Закона № 135-Ф3 [11]. Для того, чтобы обеспечить надлежащее нормативно-правовое регулирование в данной сфере необходимо:

На уровне законодательства субъектов РФ: предусмотреть в законодательстве ряд исключения для проведения закупочных процедур в отношении имущества, находящегося в собственности государства или муниципального образования. Например, на уровне г. Москвы предлагается включить в раздел 45 Типового положения п. 45.1.20 в формулировке:

«Заключается договор аренды муниципального или государственного имущества».

На федеральном уровне: включить в подп. 3 п. 1 ст. 17.1 Закона РФ № 135-Ф3 фразу «а также хозяйственными обществами, доля участия государства, муниципального образования, субъекта РФ, в уставном капитале которых в совокупности превышает 50\%» (сразу после слов «муниципальным учреждениям»).

Проведенное исследование подтверждает актуальность комплексного и глубокого изучения механизма нормативно-правового регулирования аренды государственного и муниципального имущества с учетом присущих ему особенностей. Законодательство, регулирующее арендные отношения, отстает от реальных потребностей реализации института аренды государственного и муниципального имущества, а потому нуждается в усовершенствовании. Наличие нерешенных проблем института аренды и законодательных пробелов в сфере нормативно-правового регулирования также свидетельствует о высокой актуальности и практической значимости изучения отношений, возникающих при аренде муниципального и государственного имущества. 


\section{ЛИТЕРАТУРА}

1. Натаева 3.А. Правовое регулирование договора аренды нежилых помещений, не требующих государственной регистрации // Гуманитарные, социально-экономические и общественные науки. 2020. № 3. С. 129-131.

2. Блюмова А.В., Ахметшин Р.А. К вопросу правового регулирования аренды земель для размещения линейных объектов // Аллея науки. 2020. Т. 1. № 1 (40). C. 550-554.

3. Батталова Л.М. Аренда муниципального имущества: проблемы правового регулирования и практики // Проблемы экономики и юридической практики. 2020. T. 16. № 2. С. 243-247.

4. Подрезова 0.С. Особенности правового регулирования договора аренды жилых помещений // Аллея науки. 2020. Т. 1. № 3 (42). С. 497-500.

5. К Книгина 0.А. Некоторые проблемы правового регулирования договора аренды // Эволюция российского права. Материалы XVIII Заочной международной научной конференции молодых ученых и студентов. Уральский государственный юридический университет. 2020. С. 88-89.

6. Зуева А.А. Аренда как экономический метод регулирования земельных отношений // Научные труды студентов Ижевской ГСХА. [Электронное издание]. отв. за выпуск Н.М. Итешина., Ижевск, 2020. С. 1073-1078.

7. Глезденева М.А. Правовое регулирование проведения торгов при продаже и аренде государственного и муниципального имущества // Студенческий вестник. 2020. № 23-2 (121). С. 48-50.

8. Барсукова Г.Н., Пшидаток С.К. К вопросу правового регулирования аренды земельных участков // Научно-технологическое обеспечение агропромышленного комплекса России: проблемы и решения. Сборник тезисов по материалам IV Национальной конференции. Отв. за выпуск А.Г. Кощаев. 2019. С. 124.

9. К Клименко С.А. Современные тенденции правового регулирования аренды земельных участков в РФ // Научные исследования и разработки последнего десятилетия: взаимодействие прошлого и современного. Материалы XXII Всероссийской научно-практической конференции. 2019. С. 56-59.

10. Ручкина Г.Ф. Правовое регулирование отношений по аренде земельных участков при осуществлении предпринимательской деятельности // Предпринимательское право. 2020. № 3. С. 11-17.

11. Константинов Д.Р. Понятие договора аренды и его правовое регулирование // Пермский период. Сборник материалов научно-практической конференции в рамках VII Международного научно-спортивного фестиваля курсантов и студентов. В 2-х томах. Составитель В.А. Овченков. ФКОУ ВО Пермский институт ФСИН России, 2020. С. 19-22.

(c) Шайдуллина Венера Камилевна (KShajdullina@fa.ru).

Журнал «Современная наука: актуальные проблемы теории и практики»

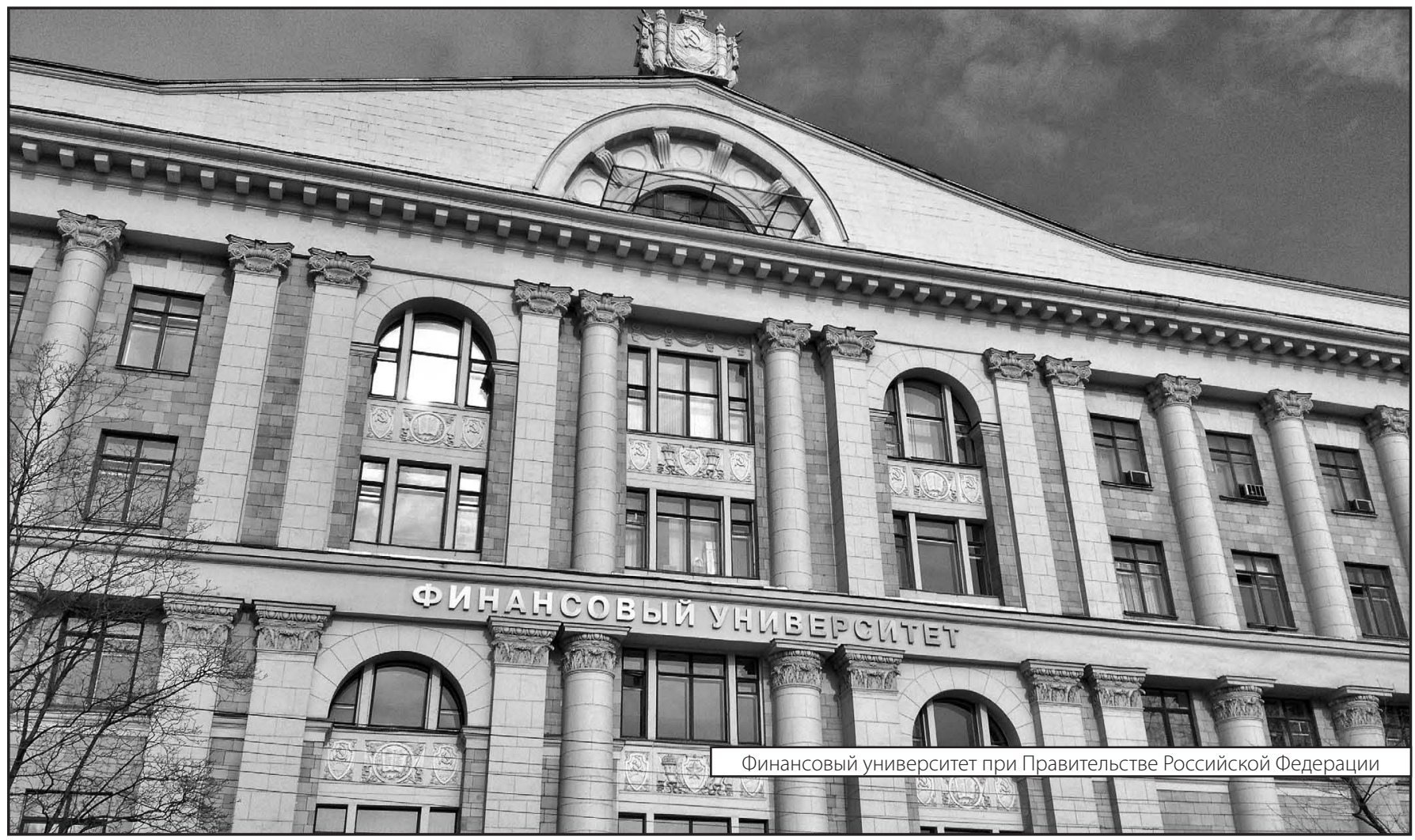

